\title{
Distribution of a tetrabrominated diphenyl ether and its metabolites in soft-bottom sediment and macrofauna species
}

\author{
Kerstin Magnusson*, Stefan Agrenius, Rolf Ekelund \\ Department of Marine Ecology, Göteborg University, Kristineberg Marine Research Station, 45034 Fiskebäckskil, Sweden
}

\begin{abstract}
Sediment spiked with ${ }^{14} \mathrm{C}-2,2$ ' , 4, 4'-tetrabrominated diphenyl ether (BDE-47) was added as a single pulse, at a low or a high concentration, to intact soft-bottom sediments in a box-cosm system. The vertical distribution of the pollutant and the bioaccumulation in 39 different taxa of macrofauna were analysed after 10, 20 and $29 \mathrm{wk}$ exposure. Throughout the experimental period, $90 \%$ of the recovered BDE-47-derived radioactivity in the sediment was found within the upper $5 \mathrm{~cm}$. The BSAF (biota-sediment accumulation factor) in the different taxa after $29 \mathrm{wk}$ exposure varied between 0.4 and 16.3. The correlation between bioaccumulation and lipid content of all individual specimens in each box-cosm was significantly positive and explained between 11 and $64 \%$ of the variation. When the fauna was divided into groups with different feeding strategies, it was found that the mean BSAF was significantly higher for the surface deposit-feeders than for the suspension-feeders, subsurface feeders and the predators. The difference increased with time and was larger after 29 wk exposure than after $10 \mathrm{wk}$. We also tested whether there was a correlation between ${ }^{15} \mathrm{~N}$ enrichment, i.e. trophic position, in the analysed species and bioaccumulation, but no such correlation was found. Water-soluble metabolites of BDE-47 were detected in 15 of the 39 macrofaunal species. There was no observable correlation between the presence of metabolites in the macrofauna and bioaccumulation of the pollutant.
\end{abstract}

KEY WORDS: Bioaccumulation · Biotransformation $\cdot$ Hydrophilic metabolite $\cdot$ Bioturbation $\cdot$ Sediment Polybrominated diphenyl ethers

\section{INTRODUCTION}

The polybrominated diphenyl ethers (PBDEs) are anthropogenically produced organic substances with a main application as flame retardants. They have been extensively used since the early 1970s, and since the mid-90s have received attention as a potentially very serious threat to the environment. Chemically they resemble many other hydrophobic organic pollutants, e.g. the PCBs, and several field studies have confirmed that the concentrations in biota are high (Jansson et al. 1993) and are increasing dramatically (Norén \& Meironyté 2000). Like the PCBs the PBDEs consist of 209 congeners, and in field samples the tetra-brominated 2,2', 4,4'-BDE (BDE47) has been found to be one of the most predominant congeners (Sellström et al. 1998, Lindström et al. 1999).
Hydrophobic organic molecules have a high affinity for organic particles, and coastal marine sediments have therefore over the years become important deposits for this kind of pollutants. Since sediment-living animals often have high weight-specific ingestion rates of sediment (Lopez \& Levinton 1987), their uptake of organic pollutants through ingested food material can be very high (Boese et al. 1990, Forbes et al. 1998). To what extent organic pollutants are accumulated in sedimental fauna varies between species (Strandberg et al. 2000, Goerke \& Weber 2001), but the underlying mechanism for this is not totally defined. It was suggested by DiToro et al. (1991) that organic pollutants partition between different matrices, e.g. an organism, water and sediment, so that a chemical equilibrium is established. Differences in bioaccumulation between species and between individuals of the same species would thus only be the result of differences in 
lipid content, provided that exposure concentrations had been the same. There are however variations in pollutant concentrations that remain even after normalisation to lipid content has been made (Lake et al. 1990, Strandberg et al. 2000), implying that there are additional explanatory factors involved. One problem is to accurately determine the pollutant concentration the animal has actually been exposed to, since this depends not only on the concentration in the bulk sediment but also on the feeding strategy of the animal. The uptake of hydrophobic organic pollutants occurs both over respiratory and dermal surfaces, and over the gut epithelium, but for sediment-living animals the uptake in the gut is most important. Many sedimentliving animals have the capacity to selectively ingest particles with a higher organic content than bulk sediment (Lee et al. 1990). Since organic pollutants are predominantly associated with the organic fraction of the sediment, species with a more selective feeding mode thus should have a higher pollutant concentration in the gut than less selective species.

It has also been suggested that bioaccumulation of organic hydrophobic pollutants is affected by the position of the species in the food web. If the lipid-based concentration of the pollutant becomes higher in a predator than in its prey (i.e. it increases with increased trophic level in the food web) it is considered to biomagnify (Mackay \& Fraser 2000). Biomagnification is known to occur in aquatic food webs for superhydrophobic compounds with $\log K_{\text {ow }}>6.3$, where $K_{\text {ow }}$ is an octonol-water partition coefficient (Cabana \& Rasmussen 1994, Russell et al. 1999). Often food webs are defined from the ecological knowledge of the feeding behaviour of each species. An alternative approach that has gained more and more interest is to determine trophic levels through measurement of the stable nitrogen-isotope ratio $\left({ }^{15} \mathrm{~N} /{ }^{14} \mathrm{~N}\right)$ in the tissues. This method is based on the fact that the proportion of ${ }^{15} \mathrm{~N}$ in animals increases relative to that in their food, so that a higher ${ }^{15} \mathrm{~N} /{ }^{14} \mathrm{~N}$ ratio implies a higher trophic level (Hobson \& Welch 1992, Cabana \& Rasmussen 1994). A positive correlation between an increased proportion of ${ }^{15} \mathrm{~N}$ and a lipid-based concentration of organic pollutants has been detected in pelagic food webs (Cabana \& Rasmussen 1994). In the present study, we investigated whether such a correlation existed also in a benthic community. Benthic food chains normally span fewer trophic levels than pelagic chains, and there are often broad overlaps between species due to the common occurrence of omnivores (France et al. 1998, Kaehler et al. 2000); nevertheless biomagnification would still be theoretically possible.

Biotransformation of organic pollutants has a strong influence on their fate in the environment, including bioaccumulation. An efficient metabolic conversion of a hydrophobic compound into more water-soluble metabolites makes the compounds less inclined to bioaccumulate. This is very striking when comparing polycyclic aromatic hydrocarbons (PAHs) with halogenated organic hydrocarbons. The former are quite readily metabolised by most species and consequently do not bioaccumulate to a very large extent (Broman et al. 1990), whereas the capacity to metabolise the latter is generally much lower, and as a result these compounds tend to reach high concentrations in living organisms. Information on metabolism of PBDEs is very limited, and to our knowledge no studies have been made on invertebrates. In the present study we examined the occurrence of water-soluble metabolites of BDE-47 in a large number of invertebrate species. Although this does not reveal the metabolic turnover rates, it does provide information on whether there has been any metabolism at all.

In summary, we studied several aspects of the fate of BDE-47 in a marine sedimental ecosystem, observing variations in bioaccumulation between both macrofauna species and between individuals of the same species over time in the light of various factors - the lipid content of the animals, their feeding strategy, their trophic position in the food web and their capacity to metabolically convert the compound.

\section{MATERIALS AND METHODS}

Experimental set-up. The experiment was performed in a system of box-cosms containing a fairly intact softbottom sediment (Berge et al. 1986). Plexiglas boxes, $50 \times 50 \times 40 \mathrm{~cm}$, were fitted into a sediment grab, and 12 samples were collected at $60 \mathrm{~m}$ depth in the Gullmar fjord on the Swedish west coast in February 1999. In the laboratory, the 12 box-cosms were fitted with lids and kept in the dark at $5^{\circ} \mathrm{C}$ with a flow-through of natural seawater throughout the experimental period. Each box also had an internal water circulation to prevent the build-up of nutrient and oxygen gradients at the sediment-water interface. The faunal and microbial communities of the boxes, as well as the fluxes of inorganic nutrients over the sediment-water interface, have been shown to resemble those of a field situation even after 7 mo incubation (Dahllöf et al. 2001, S. Molander et al. unpubl. data).

Pollutant. We used radiolabelled and unlabelled 2,2', 4, 4'-tetrabromodiphenyl ether (BDE), named BDE-47 in accordance with the IUPAC (International Union of Pure and Applied Chemistry) nomenclature for PCBs. The radiolabelled compound, ${ }^{14} \mathrm{C}-2,22^{\prime}, 4,4^{\prime}-$ $\mathrm{BDE}$, had a specific activity of $73.8 \mu \mathrm{Ci} \mathrm{mmol}^{-1}$.

Spiking and dosing of sediment. Of the 12 boxcosms, 6 received a low dose of BDE-47 (L-boxes) and 
6 received a high dose (H-boxes). The contaminant was added as spiked sediment prepared in the following way: To each of 12 glass jars we added $8.9 \mu \mathrm{Ci}$ $(0.12 \mu \mathrm{mol}){ }^{14} \mathrm{C}$-BDE-47 dissolved in chloroform. Unlabelled substance was then added in a low dose $(0.255 \mu \mathrm{mol})$ to half of the jars and in a high dose (3.63 $\mu \mathrm{mol})$ to the other half, resulting in a total dose (labelled and unlabelled substance) of $0.375 \mu \mathrm{mol}$ in each of the jars prepared for the L-boxes and $3.75 \mu \mathrm{mol}$ in the jars prepared for the H-boxes. The solvent was allowed to evaporate as the jars were agitated, leaving the BDE-47 adsorbed to the glass walls.

Surface sediment collected from the same site as the box-cosms was used for spiking with BDE-47. It was sieved (250 $\mu \mathrm{m}$ mesh-size) and mixed with seawater. $100 \mathrm{ml}$ of the slurry were added to each of the BDE-47coated jars, which were then shaken for $21 \mathrm{~d}$ at $5^{\circ} \mathrm{C}$.

The box-cosms were left to acclimate in the laboratory before the addition of the spiked sediment. After $30 \mathrm{~d}$, the lids were taken off the boxes and the contents of the jars were spread in a layer (a few millimetres thick) on the sediment surface. We dosed 6 box-cosms with the low concentration $\left(0.375 \mu \mathrm{mol}\right.$ BDE- $\left.47 \mathrm{box}^{-1}\right)$, and 6 with the high concentration $\left(3.75 \mu \mathrm{mol} \mathrm{box}^{-1}\right)$, but the amount of radiolabelled substance was always the same. Out-flowing water was led through polyurethane foam (PUF) plugs to trap BDE-47 leaving the system.

The concentration of radiolabelled substance in the 2 treatments was such that 1000 disintegrations per minute $(\mathrm{dpm})$ corresponded to $19 \mathrm{pmol}$ total BDE-47 in the L- and $190 \mathrm{pmol}$ in the H-box-cosms. The added amounts of the pollutant gave concentrations which were within the range of those found in sewage sludge, natural marine sediments (Nylund et al. 1992) and in biota (Norén \& Meironyté 2000).

Sampling of boxes. We sampled $2 \mathrm{~L}$ - and $2 \mathrm{H}$-boxes after $10 \mathrm{wk}$ exposure, $2 \mathrm{~L}$ and $1 \mathrm{H}$ after $20 \mathrm{wk}(1 \mathrm{H}$-box had suffered from severe hypoxia and could not be used) and $2 \mathrm{~L}$ - and $2 \mathrm{H}$-boxes after $29 \mathrm{wk}$. On each sampling occasion, 3 sediment cores, $45 \mathrm{~mm}$ in diameter, were collected from each box for analysis of the pollutant concentration. The cores were frozen, the outer $1 \mathrm{~mm}$ was peeled off to eliminate smearing effects, and they were then cut into $1 \mathrm{~cm}$-thick slices. The sediment was freeze-dried and homogenised before extraction.

From the remaining sediment in the boxes, all fauna retained on a $4 \mathrm{~mm}$ sieve was kept for analysis. Subsampling was carried out only for the 3 dominant species, the brittle stars Amphiura chiajei and A. filiformis and the polychaete Melinna cristata, of which 8 individuals were analysed from each box. For all other species, each individual was analysed and included in the results.

After collection, the animals were left for $12 \mathrm{~h}$ in clean water to clear their guts of contaminated sedi- ment. They were then kept frozen until analysis. In the case of Abra nitida and Nucula spp., individuals were pooled to obtain sufficient biomass, otherwise all extractions were carried out on individual animals. The guts of the sea urchins Brissopsis lyrifera and Echinocardium spp. were removed and thoroughly rinsed before being frozen together with the rest of the soft tissues. All animals were freeze-dried and homogenised before extraction.

Extraction procedures. Sediment and fauna were treated as follows:

Sediment: A subsample of approximately $1 \mathrm{~g}$ dry weight was taken from each $1 \mathrm{~cm}$-thick slice of sediment. The samples were extracted by sonication using $10 \mathrm{ml}$ hexane:acetone (47:53) as a solvent. After centrifugation the supernatants were transferred to scintillation vials and $15 \mathrm{ml}$ of scintillation fluid were added. We considered it unnecessary to perform a second extraction, since a test showed that this increased the recovery of ${ }^{14} \mathrm{C}$-BDE-47-derived radioactivity by no more than a few percent.

A pilot study was run to investigate whether there were any detectable amounts of water-soluble metabolites in the bulk sediment: 1 sediment core from 1 boxcosm from each sampling occasion, i.e. at 10, 20 and $29 \mathrm{wk}$, was extracted with chloroform:methanol in the same way as for the fauna. Radioactivity in the methanol-water phase was considered to derive from ${ }^{14} \mathrm{C}$-BDE metabolites.

Fauna: The bioaccumulation of ${ }^{14} \mathrm{C}-\mathrm{BDE}-47$ and the ratio between organic-soluble and methanol-watersoluble BDE-47-derived radioactivity was analysed in a total of 688 specimens belonging to 39 different taxa (see Table 2). Extraction was carried out by sonication using chloroform:methanol-water as solvents in order to separate the ${ }^{14} \mathrm{C}$-BDE-47-derived radioactivity into 2 fractions with different polarity and also to determine the total tissue lipid content. The method was modified by Silversand \& Haux (1995) from that of Bligh \& Dyer (1959). The animals were individually freeze-dried in test tubes and carefully grounded with a glass rod. $1.3 \mathrm{ml}$ water, $2 \mathrm{ml}$ chloroform and $4 \mathrm{ml}$ methanol were added to the sample which was then sonicated for $30 \mathrm{~s}$. Another $2 \mathrm{ml}$ of chloroform were added before a second sonication for $30 \mathrm{~s}$. The sample was centrifuged $(2500 \times g)$ and the supernatant was transferred to a clean test tube. We added $4 \mathrm{ml}$ chloroform:methanol $(1: 1, v / v)$ to the pellet, which was then sonicated for another $30 \mathrm{~s}$ and centrifuged. The 2 supernatants were combined and $4.1 \mathrm{ml}$ of $0.88 \% \mathrm{KCl}$ solution were added to remove non-lipid components. The samples were mixed vigorously and left to separate at $4^{\circ} \mathrm{C}$ overnight. The chloroform phase, containing the extracted lipids, was carefully separated from the methanol-water phase and evaporated to dryness in 
small glass vials. Lipid content was determined gravimetrically. The glass vials with the lipids and the associated non-polar forms of the ${ }^{14} \mathrm{C}-\mathrm{BDE}-47$ and the methanol phases (assumed to contain the more watersoluble metabolites) were then transferred to scintillation vials to which $15 \mathrm{ml}$ of scintillation fluid were added.

A test was performed to validate whether the radioactivity in the methanol phase derived from metabolites of the parent compound or from the parent compound itself. Uncontaminated animals, representing most species that were analysed in the experiment, were freezedried and carefully ground. The extraction was carried out in the same way as for the rest of the fauna except that ${ }^{14} \mathrm{C}-\mathrm{BDE}-47$, in an amount of $1 \mathrm{nCi} \mathrm{ind.}{ }^{-1}$, was added to the first portion of chloroform.

The activity in the methanol phases was approximately $50 \pm 5 \mathrm{dpm}$, which corresponded to $2.2 \%$ $( \pm 0.9 \%)$ of the total added radioactivity; $50 \mathrm{dpm}$ was thus subtracted as a background value from all methanol samples. The radioactivity in the chloroform and the methanol phases from the animals and in the sediment extracts was measured in a Beckman LSC with an H-number quench monitor.

Calculation of biota sediment accumulation factor (BSAF). The relationship between the concentration of ${ }^{14} \mathrm{C}-\mathrm{BDE}-47$ in the biota and in the surrounding sediment was expressed using the BSAF, a factor based on the assumption that organic hydrophobic compounds, such as the PBDEs, partition predominantly between the lipids of the organisms and the organic carbon of the sediment. The lipid/organic carbon normalisation has been shown to reduce the variability in bioaccumulation data of (e.g.) PCB (Lake et al. 1990).

BSAF $=\frac{{ }^{14} \mathrm{C}-\mathrm{BDE}-47 \text {-derived radioactivity in the animal } \mathrm{g}^{-1} \text { lipid }}{{ }^{14} \mathrm{C}-\mathrm{BDE}-47 \text {-derived radioactivity in the sediment } \mathrm{g}^{-1} \text { organic } \mathrm{C}}$

The calculations were based on the radioactivity in the chloroform phase of the animal extracts and the total radioactivity in the hexane:acetone extracts of the upper $1 \mathrm{~cm}$ of the sediment. The BDE- 47 concentration in the sediment was very patchy and it can be debated what part of the sediment should be used for the BSAF calculations. The fauna will be exposed to different concentrations depending on how they move around, so it is in reality impossible to find a 'true' exposure concentration for each individual specimen.

Bioaccumulation of ${ }^{14} \mathrm{C}-\mathrm{BDE}-47$ and the BSAF was determined for each individual animal. Exceptions to this were the 3 dominant species Amphiura chiajei, A. filiformis and Melina cristata, for which only 8 individuals in each box-cosm were analysed separately, and Abra nitida and Nucula spp., for which several individuals from the same box were pooled.
Division of macrofauna into feeding categories. Many species living in sediment habitats appear to be flexible and able to adapt their feeding strategies to different environmental circumstances. With this in mind we pooled the species into the following feeding categories: species mainly feeding on material deposited on the sediment surface (dep), species mainly feeding on organic matter in the water column (sus), species mainly feeding on organic material buried in the sediment (sub) and predacious and/or scavenging species (pre). The brittlestar Amphiura filiformis feeds mainly on suspended material when water movement is sufficient, and on deposited material when water movement is slower. In this study A. filiformis is classified as a suspension feeder, since the stream velocity in the boxes was above $0.5 \mathrm{~cm} \mathrm{~s}^{-1}$, which is the threshold velocity above which they have at least 1 arm stretched up into the water column (Loo et al. 1996). Several burrowing spatangoid sea urchins are known to regulate their feeding depth in the sediment in accordance with the availability of food resources. Brissopsis lyrifera moves up and feeds from the sediment surface when organic material is deposited there (Hollertz 1998), and Echinocardium cordatum is known to feed from the sediment surface (De Ridder 1982). In the present study, the spiked sediment was added to the sediment surface; this consisted of smaller particles with a higher organic content than the bulk sediment. Under these circumstances, we considered it most appropriate to classify the sea urchins in the boxcosms as surface deposit feeders. The polychaete Maldane sarsi, anthozoans of the family Edwardsidae, and the mollusc Xenoturbella boecki are not included in this classification since we have no knowledge of their feeding behaviour.

${ }^{15} \mathbf{N} /{ }^{14} \mathbf{N}$ analysis. We analysed 3 samples of surface sediment and 32 specimens representing 15 different species to determine ${ }^{15} \mathrm{~N}$ content, using a Carlo Erba element analyser connected to an Optima isotope mass spectrometer and atmospheric $\mathrm{N}_{2}$ as a standard. The isotope ratios are expressed in parts per thousand according to the relationship $\delta^{15} \mathrm{~N}=\left(\left[{ }^{15} \mathrm{~N} /{ }^{14} \mathrm{~N}_{\text {sample }} /\right.\right.$ $\left.\left.{ }^{15} \mathrm{~N} /{ }^{14} \mathrm{~N}_{\text {air }}\right]-1\right) \times 10^{3}$. All animals originated from 2 boxes exposed to ${ }^{14} \mathrm{C}$-BDE-47 for $29 \mathrm{wk}$, and the analyses were made on individual specimens using the pellet remaining after chloroform:methanol extraction. The use of $\delta^{15} \mathrm{~N}$ values for determination of trophic level is based on the principle that ${ }^{15} \mathrm{~N}$ is enriched in relation to ${ }^{14} \mathrm{~N}$ in a predictable manner upwards in a food web. The enrichment has been estimated to be 3 to $4 \%$ between 2 trophic levels (Minagawa \& Wada 1984, Fry 1988, Hobson \& Welch 1992). The $\delta^{15} \mathrm{~N}$ values were compared to the accumulation of BDE-47derived radioactivity recovered in the chloroform phase of the animal extracts. 
Recovery of ${ }^{14} \mathrm{C}-\mathrm{BDE}-47$ in boxes. Data from the sediment cores were used to estimate the total recovery of ${ }^{14} \mathrm{C}$-BDE-47-derived radioactivity in the box-cosms on each sampling occasion. By using the radioactivity present $1 \mathrm{~cm}$ down in the sediment and compensating for the decrease in water content with increasing depth, the radioactivity per $\mathrm{cm}^{2}$ was estimated. These data were then extrapolated to the whole box-cosm.

Organic carbon and lipid content in sediment. For measuring organic carbon and lipid content of the sediment we used parallel samples to the sediment slices extracted with hexane:acetone; 1 core from each sampling occasion was analysed. The total organic content of the sediment was analysed with an NA 1500 NC Carlo Erba elemental analyser (Fisons) on samples pre-treated with $\mathrm{HCl}$ to remove inorganic carbon. The lipid content was determined gravimetrically in the same way as for the macrofauna samples.

Statistics. The change in BSAF with time among species was tested by non-parametric analysis of variance based on ranks (Kruskal-Wallis). Pairwise multiple comparisons were done by Dunn's method.

The changes in the BSAFs of the different feeding guilds with time were compared by a 2 -factor analysis of variance (ANOVA, $\alpha=0.05$ ). An average BSAF for each feeding guild (dep, sus, sub, and pre) in each boxcosm was calculated from the average BSAF for each species in that box. Some parameters were tested statistically (ANOVA, $\alpha=0.05$ ) for Amphiura chiajei, A. filiformis and Melinna cristata only, since these were the only species represented by a sufficiently large number of individuals. These parameters were change in lipid weight over time, changes in ${ }^{14} \mathrm{C}$-BDE47 concentration with time and changes in the relative amount of metabolites in the tissues with time.

Loss of ${ }^{14} \mathrm{C}$-BDE- 47 from the sediment with time was also tested by ANOVA $(\alpha=0.05)$.

Linear regressions were made between BDE-47 accumulation and both the lipid content (ln-transformed data) and $\delta^{15} \mathrm{~N}$ of the fauna and sediment.

\section{RESULTS}

\section{Characteristics of sediment ecosystem}

The organic carbon content of the sediment varied between 3.5 and $4.0 \%$ and the sediment lipid content between 0.20 and $0.24 \%$ of dry weight. None of the parameters changed significantly either with sediment depth or with exposure time.

The total biomass of the macrofauna investigated is shown in Table 1. The fauna was found almost exclusively in the upper $5 \mathrm{~cm}$ of the sediment and constituted 0.26 to $0.42 \%$ of the bulk sediment dry weight and 2.65 to $5.62 \%$ of the sediment lipid weight. There were no significant changes over time.

All species present and their abundance are shown in Table 2. Dominating species in all boxes were the 2 brittle stars Amphiura chiajei and A. filiformis, and the polychaete Melinna cristata. On a lipid weight basis they constituted about $60 \%$ of the total macrofauna (Table 3). The lipid content (\% dry weight) remained unchanged in $M$. cristata but decreased significantly (ANOVA, $\mathrm{p}<0.05$ ) in A. chiajei and A. filiformis between the first and the last sampling occasion.

\section{BDE-47-derived radioactivity in sediment}

Recovery of sediment-associated ${ }^{14} \mathrm{C}-\mathrm{BDE}-47$ in boxes

All box-cosms were dosed with the same amount of radiolabelled BDE-47, but the amount of cold pollutant was lower in the $\mathrm{L}$ than in the $\mathrm{H}$ treatment. To facilitate comparisons between the treatments we use the unit disintegrations per minute to express the amount of pollutant.

The total amount of sediment-associated radioactivity in the boxes decreased over time (Table 4 ), and the recovery after $29 \mathrm{wk}$ of exposure was $\leq 50 \%$ in all boxes. A few of the PUF plugs were extracted (Soxhlet extractions with hexane:acetone), and analysed for pollutant content. The analyses were not quantitative, but they did show that a considerable amount of ${ }^{14} \mathrm{C}$-BDE-47 was leaving the system with the outflowing water.

Depth distribution of ${ }^{14} \mathrm{C}-\mathrm{BDE}-47$-derived radioactivity

Between 86 and $98 \%$ of the recovered radioactivity was retained within the upper $5 \mathrm{~cm}$ of the sediment in

Table 1. Biomass (dry weight and lipid weight) of all macrofauna $>4 \mathrm{~mm}$ in the box-cosms. L: box-cosms with low ${ }^{14} \mathrm{C}$ $2,2 ', 4,4^{\prime}$-tetrabromodiphenyl ether (BDE-47) concentration; $\mathrm{H}$ : box-cosms with high concentration. At $20 \mathrm{wk}, \mathrm{H} 2$ boxcosm suffered extreme hypoxia and could not be included

\begin{tabular}{|c|c|c|c|}
\hline Box & $10 \mathrm{wk}$ & $20 \mathrm{wk}$ & $29 \mathrm{wk}$ \\
\hline \multicolumn{4}{|c|}{ Total macrofauna dry wt (g) } \\
\hline L1 & 0.54 & 0.54 & 0.38 \\
\hline L2 & 0.54 & 0.55 & 0.51 \\
\hline H1 & 0.59 & 0.63 & 0.50 \\
\hline H2 & 0.63 & & 0.63 \\
\hline \multicolumn{4}{|c|}{ Total lipid weight (g) } \\
\hline L1 & 0.23 & 0.29 & 0.16 \\
\hline L2 & 0.26 & 0.22 & 0.23 \\
\hline H1 & 0.26 & 0.24 & 0.18 \\
\hline $\mathrm{H} 2$ & 0.29 & & 0.34 \\
\hline
\end{tabular}


Table 2. Recovered macrofauna species $>4 \mathrm{~mm}$ and number of individuals found in box-cosms exposed to low (L) or high (H) BDE-47 concentration for 10, 20 and $29 \mathrm{wk}$

\begin{tabular}{|c|c|c|c|c|c|c|c|c|c|c|c|}
\hline \multirow[t]{2}{*}{ Species } & \multirow{2}{*}{$\overline{\mathrm{L} 1}$} & \multicolumn{2}{|c|}{$-10 \mathrm{wk}-$} & \multirow{2}{*}{$\overline{\mathrm{H} 2}$} & \multicolumn{3}{|c|}{$\begin{array}{l}\text { Species abundances } \\
\end{array}$} & \multirow[b]{2}{*}{ L1 } & \multicolumn{2}{|c|}{$-29 \mathrm{wk}-$} & \multirow[b]{2}{*}{$\mathrm{H} 2$} \\
\hline & & L2 & H1 & & L1 & L2 & H1 & & L2 & H1 & \\
\hline Abra nitida ${ }^{\mathrm{a}}$ & 16 & 5 & 18 & 26 & 10 & 1 & 12 & - & - & 20 & 21 \\
\hline Amphicteis gunneri & - & - & - & - & - & - & - & - & 1 & - & - \\
\hline Amphiura chiajei ${ }^{\mathrm{b}}$ & 37 & 28 & 47 & 45 & 40 & 38 & 57 & 22 & 35 & 42 & 43 \\
\hline Amphiura filiformis $^{\mathrm{b}}$ & 74 & 61 & 60 & 79 & 65 & 71 & 30 & 37 & 64 & 54 & 62 \\
\hline Anobothreus gracilis & - & - & - & - & - & - & - & 1 & - & - & - \\
\hline Aphrodita aculeata & - & - & - & - & - & - & 1 & - & - & - & 3 \\
\hline Brissopsis lyrifera & - & 2 & 1 & 1 & 2 & - & - & - & - & - & 7 \\
\hline Callocaris macandreae & - & - & - & 1 & 1 & - & 1 & - & - & - & - \\
\hline Cardium minimum & - & 2 & - & - & - & - & - & - & - & - & - \\
\hline Cerianthus lloydii & 1 & - & 1 & - & 2 & - & - & - & - & - & 1 \\
\hline Chaetoderma nitidulum & - & - & - & - & 2 & - & - & - & - & - & 3 \\
\hline Echinocardium spp. & 2 & 1 & - & 1 & 3 & 4 & 1 & - & 1 & 1 & 3 \\
\hline Edwardsidae & - & - & - & 1 & 1 & - & - & - & 2 & 2 & 1 \\
\hline Eriopisa elongata & 2 & 1 & 6 & - & - & - & - & - & 2 & - & - \\
\hline Euchone papillosa & - & - & - & - & - & - & 1 & - & - & - & - \\
\hline Gattyana spp. & - & - & 1 & - & - & - & - & 1 & 2 & - & - \\
\hline Glycera spp. & 1 & - & 1 & 1 & 1 & - & 1 & - & 1 & - & 2 \\
\hline Goniada maculata & - & - & - & - & - & - & - & - & 1 & 1 & - \\
\hline Maldane sarsi & - & 1 & 1 & 9 & 6 & 4 & 1 & 8 & 8 & 6 & 4 \\
\hline Melinna cristata ${ }^{b}$ & 21 & 61 & 60 & 59 & 62 & 41 & 51 & 50 & 87 & 62 & 76 \\
\hline Nemertini & 1 & - & - & - & - & - & - & - & 1 & 1 & 1 \\
\hline Nephtys spp. & 1 & 2 & 1 & 2 & - & 1 & 1 & 1 & 2 & - & 1 \\
\hline Nereis spp. & - & - & 2 & 1 & - & 1 & - & - & - & - & - \\
\hline Nucula spp. ${ }^{a}$ & 10 & - & - & 12 & 13 & - & 2 & - & - & 8 & - \\
\hline Nuculana pernula & 3 & - & 1 & 2 & 4 & 1 & 2 & 2 & 2 & 3 & 4 \\
\hline Ophiura spp. & - & 3 & 1 & 2 & - & 4 & - & - & 3 & 3 & 1 \\
\hline Orbinia norvegica & - & - & - & 1 & 1 & - & - & 1 & 1 & - & - \\
\hline Pectinaria spp. & - & 1 & 1 & - & 1 & 1 & 1 & - & - & - & - \\
\hline Pholoe spp. & - & - & 1 & 1 & - & - & - & 1 & - & - & 6 \\
\hline Polycirrus spp. & - & - & 1 & - & - & - & - & - & - & 1 & - \\
\hline Polynoidae & - & - & 1 & 1 & - & - & - & - & - & - & - \\
\hline Polyphysia/Lipobranchus & - & - & 1 & 2 & 2 & - & - & - & 1 & 2 & 2 \\
\hline Rhodine lovenii & - & - & - & - & - & - & - & 1 & 1 & 1 & - \\
\hline Scallibregma inflatum & - & - & 1 & - & - & - & - & - & 1 & 3 & 2 \\
\hline Terebellides stroemi & - & - & - & - & - & - & - & - & - & 1 & - \\
\hline Thyasira spp. & 2 & 1 & 2 & 3 & - & - & 1 & 2 & 5 & 4 & - \\
\hline Trichobranchus roseus & - & - & - & - & - & - & - & - & - & - & 1 \\
\hline Turbellaria & - & - & - & - & - & - & - & - & - & 1 & - \\
\hline Xenoturbella boecki & - & - & - & 1 & 1 & - & 1 & - & - & 2 & 1 \\
\hline
\end{tabular}

all boxes throughout the 29 wk experimental period, but the vertical distribution was more even after 29 than after $10 \mathrm{wk}$ (Fig. 1). This was mainly due to loss of the pollutant from the upper $3 \mathrm{~cm}$ where the radioactivity decreased over time in all boxes, but significantly less in the L- than in the H-box-cosms (ANOVA, $\mathrm{p}<0.05)$.

After 10 wk exposure, the downward mixing of the pollutant had been more efficient in the $\mathrm{H}$ - than in the L-box-cosms. In the H-boxes the radioactivity at 4 to $5 \mathrm{~cm}$ depth was almost the same after 29 wk as after $10 \mathrm{wk}$ exposure, indicating that the major downward mixing had taken place during the first $10 \mathrm{wk}$ of exposure. In the L-boxes, the process had been slower: radioactivity at 4 to $5 \mathrm{~cm}$ was very low after $10 \mathrm{wk}$, but increased thereafter. Below $5 \mathrm{~cm}$, radioactivity was only slightly above the detection limit in all boxes at all times.

Both the horizontal and vertical distribution of radioactivity varied considerably between and within boxes.

\section{Metabolites in sediment}

All 3 sediment cores extracted with chloroform:methanol-water displayed radioactivity in the methanolwater phase, indicating the presence of hydrophilic metabolites of ${ }^{14} \mathrm{C}-\mathrm{BDE}-47$ (data not shown). 
Table 3. Data on dominant macrofauna species in boxcosms, showing biomass expressed as percentage of total macrofauna biomass (dry wt and lipid wt), lipid content of individual specimens ( $\%$ of dry wt) and content of ${ }^{14} \mathrm{C}-\mathrm{BDE}$ 47 -derived radioactivity ( $\%$ of total radioactivity in the boxes). Means $\pm \mathrm{SD}$

\begin{tabular}{|lccc|}
\hline Parameter & $10 \mathrm{wk}$ & $20 \mathrm{wk}$ & $29 \mathrm{wk}$ \\
\hline Biomass (dry wt) & & & \\
Amphiura chiajei & $32.1( \pm 7.0)$ & $38.9( \pm 8.1)$ & $36.0( \pm 4.6)$ \\
A. filiformis & $36.1( \pm 7.8)$ & $28.0( \pm 9.2)$ & $31.3( \pm 4.5)$ \\
Melinna cristata & $7.2( \pm 2.4)$ & $9.0( \pm 1.8)$ & $8.1( \pm 2.1)$ \\
Biomass (lipid wt) & & & \\
A. chiajei & $19.7( \pm 4.7)$ & $24.2( \pm 8.9)$ & $18.9( \pm 5.7)$ \\
A. filiformis & $23.7( \pm 4.2)$ & $22.9( \pm 8.0)$ & $20.3( \pm 5.7)$ \\
M. cristata & $20.0( \pm 2.9)$ & $21.2( \pm 2.0)$ & $25.4( \pm 10.0)$ \\
Individual lipid content & & \\
A. chiajei & $4.3( \pm 1.4)$ & $4.9( \pm 1.2)$ & $3.4( \pm 0.8)$ \\
A. filiformis & $5.6( \pm 1.4)$ & $5.3( \pm 1.5)$ & $4.7( \pm 0.9)$ \\
M. cristata & $7.7( \pm 4.9)$ & $6.4( \pm 1.7)$ & $7.7( \pm 2.3)$ \\
BDE-47-derived radioactivity & & \\
A. chiajei & $0.86( \pm 0.23)$ & $0.98( \pm 0.60)$ & $1.00( \pm 0.37)$ \\
A. filiformis & $0.81( \pm 0.19)$ & $2.22( \pm 0.74)$ & $0.96( \pm 0.29)$ \\
M. cristata & $0.52( \pm 0.31)$ & $0.52( \pm 0.07)$ & $1.31( \pm 0.78)$ \\
\hline
\end{tabular}

Table 4. Recovery of added ${ }^{14} \mathrm{C}$-BDE-47 in box-cosms after 10 , 20 and 29 wk of exposure, and radioactivity in macrofauna expressed as \% total activity re-covered in the upper $5 \mathrm{~cm}$ of the sediment

\begin{tabular}{|c|c|c|c|c|c|c|}
\hline \multirow[t]{2}{*}{ Box } & \multicolumn{3}{|c|}{$\begin{array}{c}\text { Recovery of } \\
{ }^{14} \mathrm{C}-\mathrm{BDE}-47(\%)\end{array}$} & \multicolumn{3}{|c|}{$\begin{array}{l}\text { Radioactivity in } \\
\text { macrofauna (\%) }\end{array}$} \\
\hline & $10 \mathrm{wk}$ & $20 \mathrm{wk}$ & 29 wk & $10 \mathrm{wk}$ & $20 \mathrm{wk}$ & $29 \mathrm{wk}$ \\
\hline L1 & 92.9 & 76.1 & 53.0 & 2.1 & 1.9 & 2.7 \\
\hline L2 & 60.9 & 83.4 & 36.4 & 3.4 & 3.3 & 5.3 \\
\hline H1 & 99.5 & & 48.5 & 2.5 & 2.9 & 4.6 \\
\hline $\mathrm{H} 2$ & 79.7 & 40.2 & 37.0 & 2.6 & & 3.9 \\
\hline
\end{tabular}

\section{The animals}

Species variation in ${ }^{14} \mathrm{C}$-BDE-47 per unit dry weight

Since there was a loss of pollutant from the sediment over time, most comparisons of bioaccumulation between sampling occasions and between boxes from the same sampling occasion were made using the BSAF, since this represents the relationship between animal and sediment concentration. Still, some interesting observations of the concentration of ${ }^{14} \mathrm{C}-\mathrm{BDE}-47$ in ani-
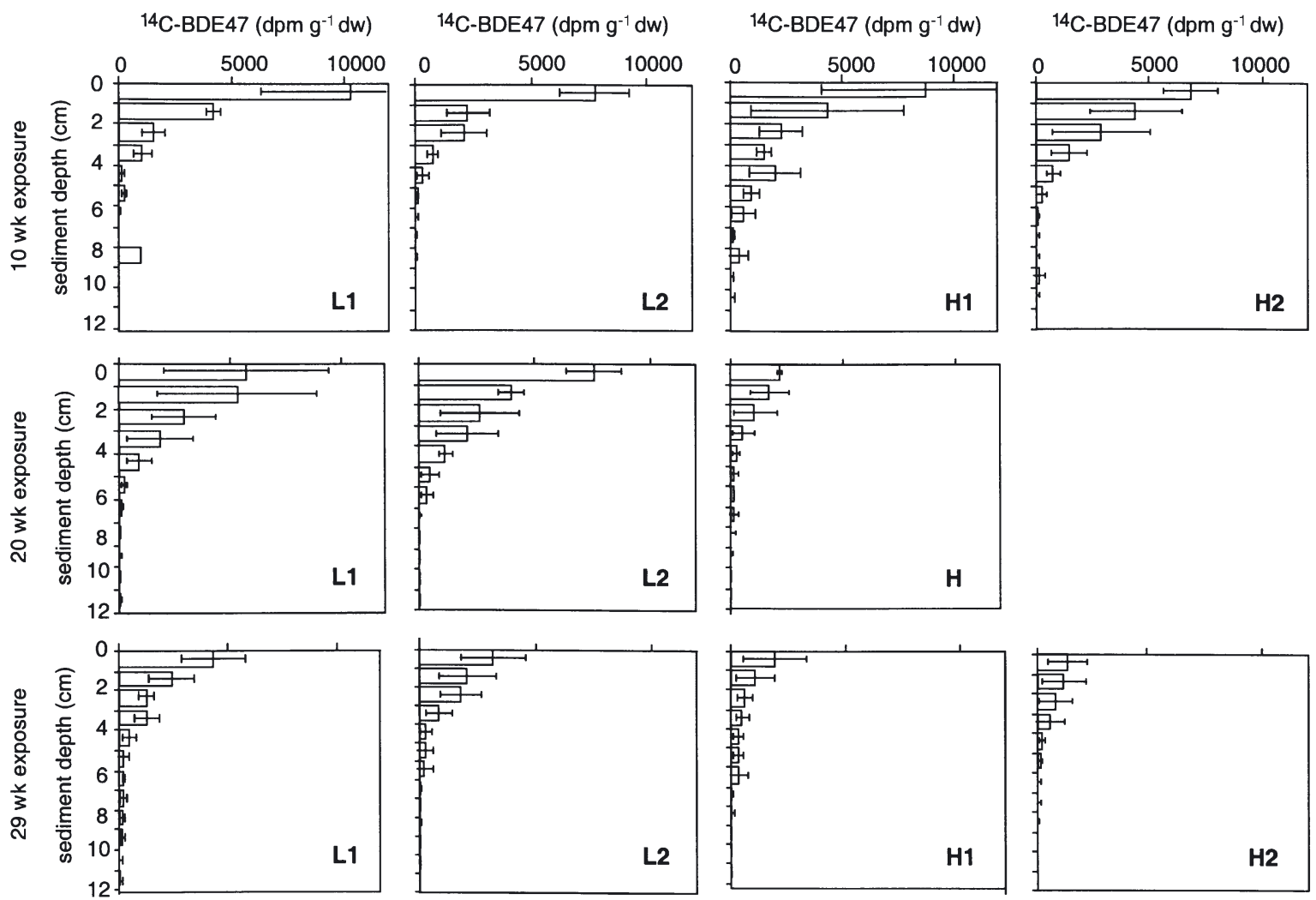

Fig. 1. Mean $( \pm \mathrm{SD}){ }^{14} \mathrm{C}$-BDE-47-derived radioactivity in sediment cores from box-cosms sampled 10, 20 and 29 wk after addition of pollutant to sediment surface. Concentration in the top $1 \mathrm{~cm}$ was used to calculate biota sediment accumulation factors (BSAFs) for the macrofauna 


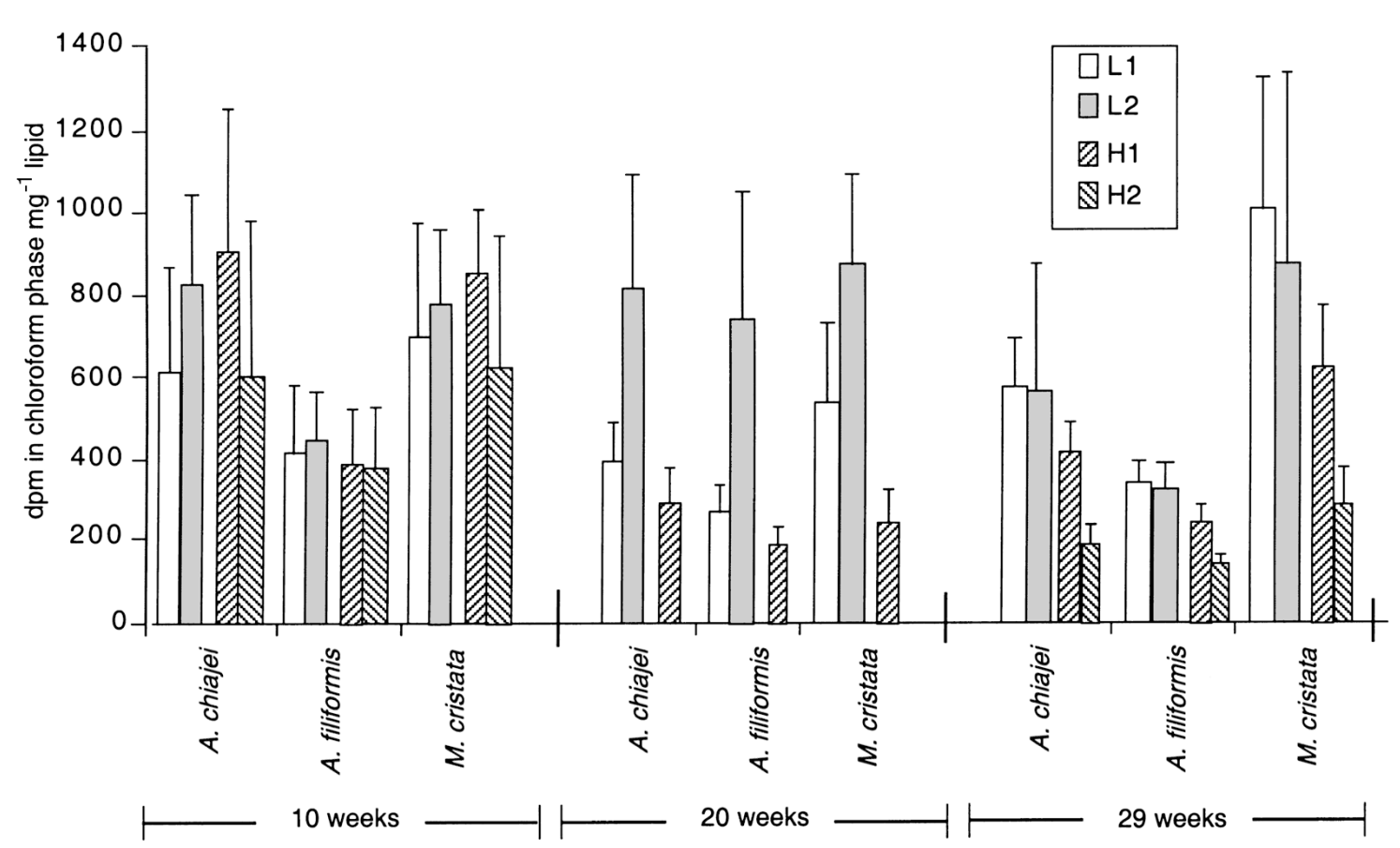

Fig. 2. Amphiura chiajei, Amphiura filiformis and Melinna cristata. Average $( \pm 95 \mathrm{CI})$ bioaccumulation of ${ }^{14} \mathrm{C}-\mathrm{BDE}-47$ in 3 dominant macrofauna species after 10, 20 and 29 wk exposure to low (L1, L2) or high (H1, H2) dose of pollutant

mals only are worth mentioning. In most species the concentration of ${ }^{14} \mathrm{C}$-BDE-47 decreased with time, but the decline in the animals was rarely as great as that in the sediment. However, a few species, e.g. Abra nitida and Echinocardium spp., had similar pollutant contents on all sampling occasions, and for Pectinaria spp. and Glycera spp. the concentrations even increased somewhat with time.

${ }^{14} \mathrm{C}-\mathrm{BDE}-47$ concentrations in the 3 dominant species are shown in Fig. 2. A significant reduction in radioactivity between 10 and 29 wk was found in all 3 species exposed to a high contaminant concentration (ANOVA, $\mathrm{p}<0.0002$ ), whereas there was no significant reduction in the low-contaminant boxes over the same period of time. This is in agreement with the greater reduction in radioactivity in the surface layer of the $\mathrm{H}$-boxes than in that of the L-boxes.

\section{BSAF}

The BSAF values of all species, on all sampling occasions (10, 20 and $29 \mathrm{wk})$, are presented in Fig. 3. Values from $\mathrm{L}$ and $\mathrm{H}$ treatments have been pooled, and in most cases they represent the mean from all individuals of each species. The exceptions are noted in Table 2. The BSAF values varied considerably between species, and they also changed with length of exposure time. The average BSAF for all species was after $10 \mathrm{wk}$
$1.91(\mathrm{SD}=1.72)$, after 20 wk $2.56(\mathrm{SD}=2.01)$ and after 29 wk 5.28 ( $\mathrm{SD}=3.48)$. Among the 19 macrofauna species that were present on all 3 sampling occasions, there was a significant increase in mean BSAF with time $(p=0.004)$. The increase was most pronounced between 20 and 29 wk of exposure.

The BSAFs for individual specimens ranged from 0.08 to 32.55 . The specimens among those species that were represented by more than 1 individual on any sampling occasion (10 wk, $\mathrm{n}=21 ; 20 \mathrm{wk}, \mathrm{n}=18$; $29 \mathrm{wk}$, $\mathrm{n}=25$ ) were not randomly scattered, but were ranked according to species $(\mathrm{p}<0.001)$ on all 3 sampling occasions.

All species were pooled into 4 feeding categories (see 'Materials and methods'), and the BSAFs increased with time for all of them (Fig. 4). Values for the surface deposit feeders were significantly higher than for all other feeding groups on all sampling occasions $(p<0.002)$. The BSAFs of the suspension feeders, subsurface deposit feeders and the predators were similar to each other at all times.

Particularly high BSAF values on all sampling occasions were found in Nuculana pernula, Amphiura chiajei, Melinna cristata, Maldane sarsi, Rhodine lovenii and Brissopsis lyrifera (Fig. 3). Values for B. lyrifera more than doubled between sampling occasions.

Low BSAFs on all sampling occasions were found for the burrowing deposit feeders Orbinia norvegica and Scallibregma inflatum and the predatory species Nereis 

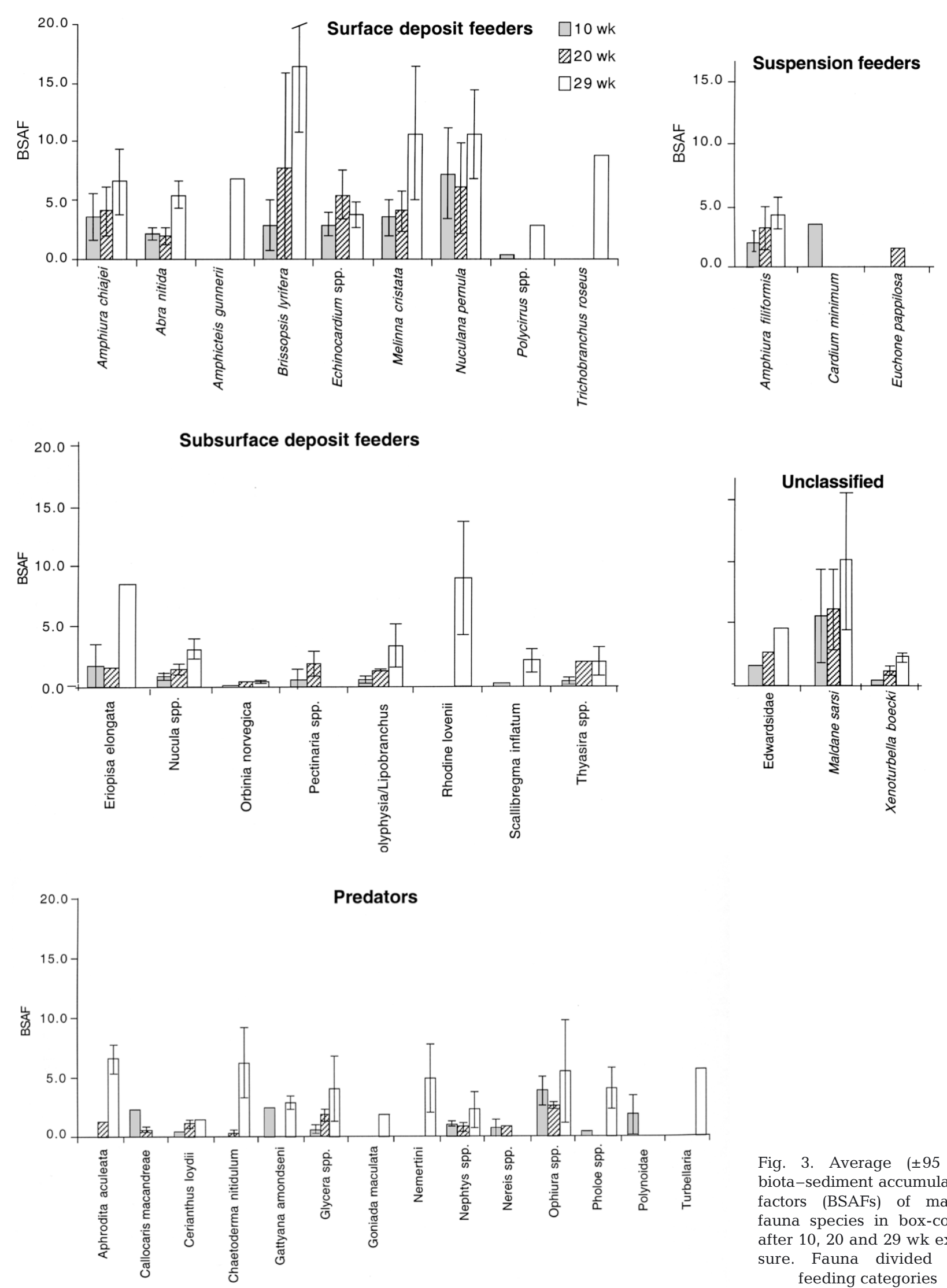

Fig. 3. Average $( \pm 95 \quad \mathrm{CI})$ biota-sediment accumulation factors (BSAFs) of macrofauna species in box-cosms after 10, 20 and 29 wk exposure. Fauna divided into feeding categories 


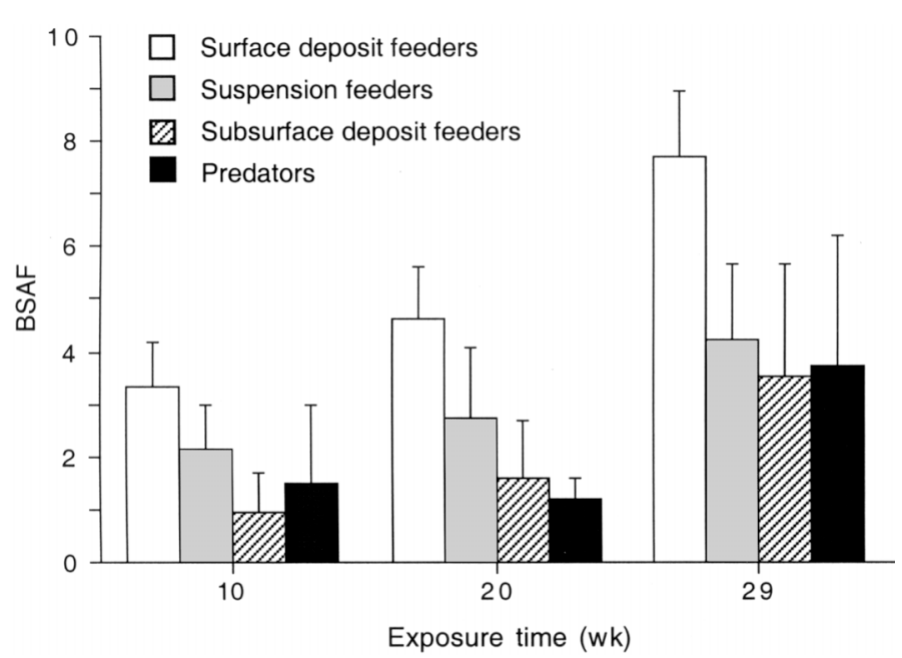

Fig. 4. Average $( \pm 95 \mathrm{CI}) \mathrm{BSAF}$ of fauna in different feeding categories after 10, 20 and 29 wk exposure

spp., Nephtys spp. and Cerianthus loydii (Fauchald \& Jumars 1979, Ruppert \& Barnes 1993). The passive suspension feeder Amphiura filiformis always took an intermediate ranking position in relation to other species.

Among the 3 dominating species, no difference in BSAF values between the $\mathrm{L}$ and $\mathrm{H}$ treatments was found on any sampling occasion (Fig. 5). Amphiura chiajei and Melinna cristata always had significantly higher values than $A$. filiformis, and after 29 wk there
Table 5. Coefficient of determination $\left(\mathrm{r}^{2}\right)$ for regressions of ${ }^{14} \mathrm{C}$-BDE-47-derived radioactivity in chloroform phase $(\mathrm{C}$, $\mathrm{dpm})$ vs lipid weight (lw, mg). Regressions are $\mathrm{C}=a+b \times$ $\ln (\mathrm{lw}+1) \cdot \mathrm{n}$ : number of specimens

\begin{tabular}{|lrrccc|}
\hline $\begin{array}{l}\text { Exposure time } \\
\text { Box }\end{array}$ & $a$ & $b$ & $\mathrm{r}^{2}$ & $\mathrm{n}$ & $\mathrm{p}$ \\
\hline 10 wk & & & & & \\
L1 & 155 & 700 & 0.25 & 44 & $<0.01$ \\
L2 & -570 & 1907 & 0.26 & 47 & $<0.01$ \\
H1 & 225 & 512 & 0.25 & 54 & $<0.01$ \\
H2 & -33 & 825 & 0.30 & 65 & $<0.01$ \\
20 wk & & & & & \\
L1 & -595 & 1339 & 0.63 & 69 & $<0.01$ \\
L2 & 118 & 1213 & 0.39 & 47 & $<0.01$ \\
H1 & -40 & 456 & 0.35 & 51 & $<0.01$ \\
29 wk & & & & & \\
L1 & 141 & 706 & 0.41 & 45 & $<0.01$ \\
L2 & 283 & 421 & 0.11 & 64 & $<0.01$ \\
H1 & -91 & 637 & 0.31 & 73 & $<0.01$ \\
H2 & -731 & 1470 & 0.64 & 76 & $<0.01$ \\
\hline
\end{tabular}

was a significant difference between all 3 species. The BSAFs in A. filiformis increased significantly with time, from 2.0 after $10 \mathrm{wk}$ to 4.1 after $20 \mathrm{wk}$ and 4.2 after 29 wk, whereas for $A$. chiajei and $M$. cristata they remained fairly constant-around 4.0 after 10 and $20 \mathrm{wk}$ - and thereafter increased significantly for both species to 6.8 and 10.6 respectively.

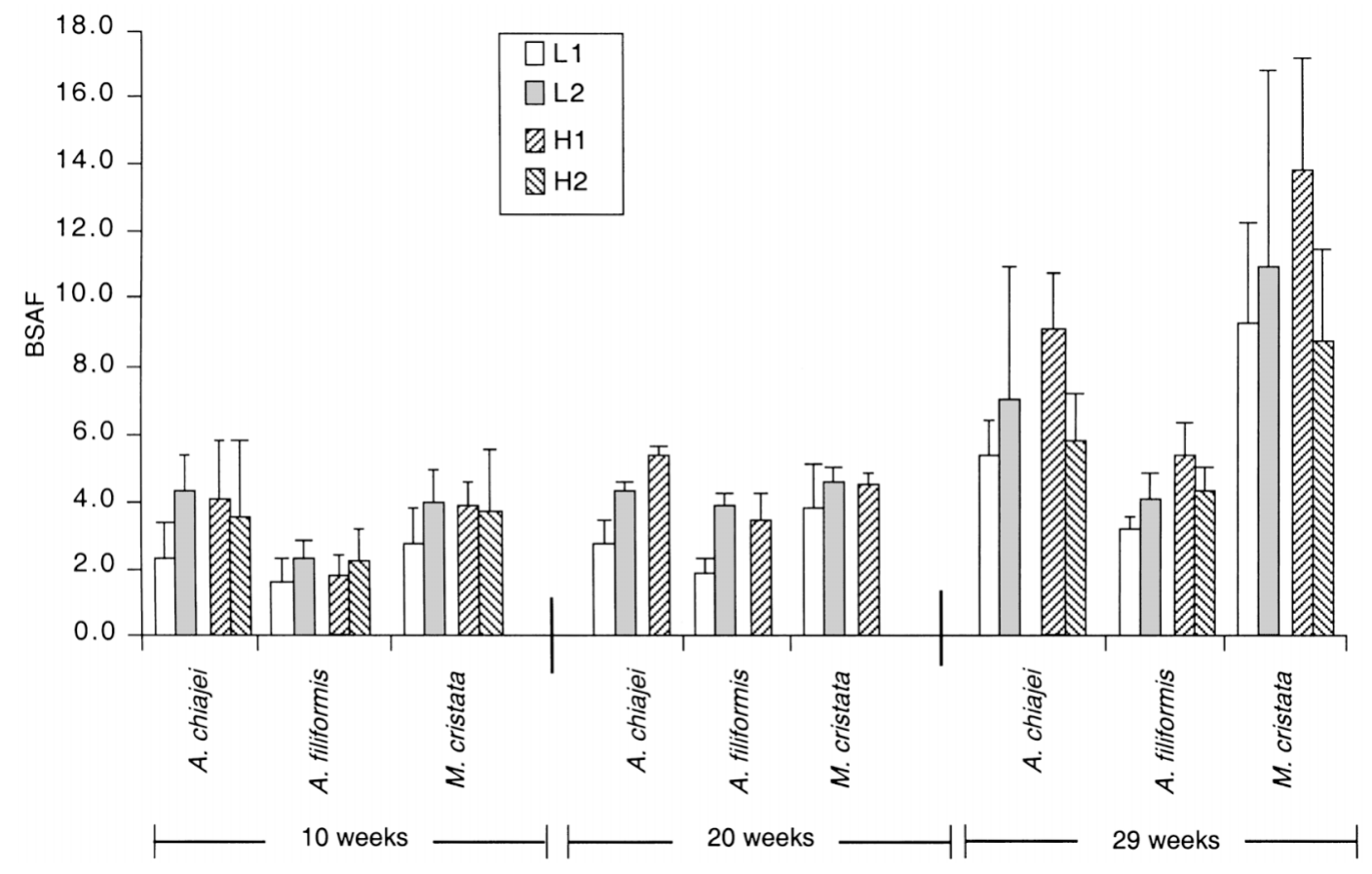

Fig. 5. Amphiura chiajei, Amphiura filiformis and Melinna cristata. Average ( $\pm 95 \mathrm{CI})$ BSAFs of 3 dominant macrofauna species after 10, 20 and 29 wk of exposure to low $(\mathrm{L} 1, \mathrm{~L} 2)$ or high $(\mathrm{H} 1, \mathrm{H} 2)$ dose of pollutant 


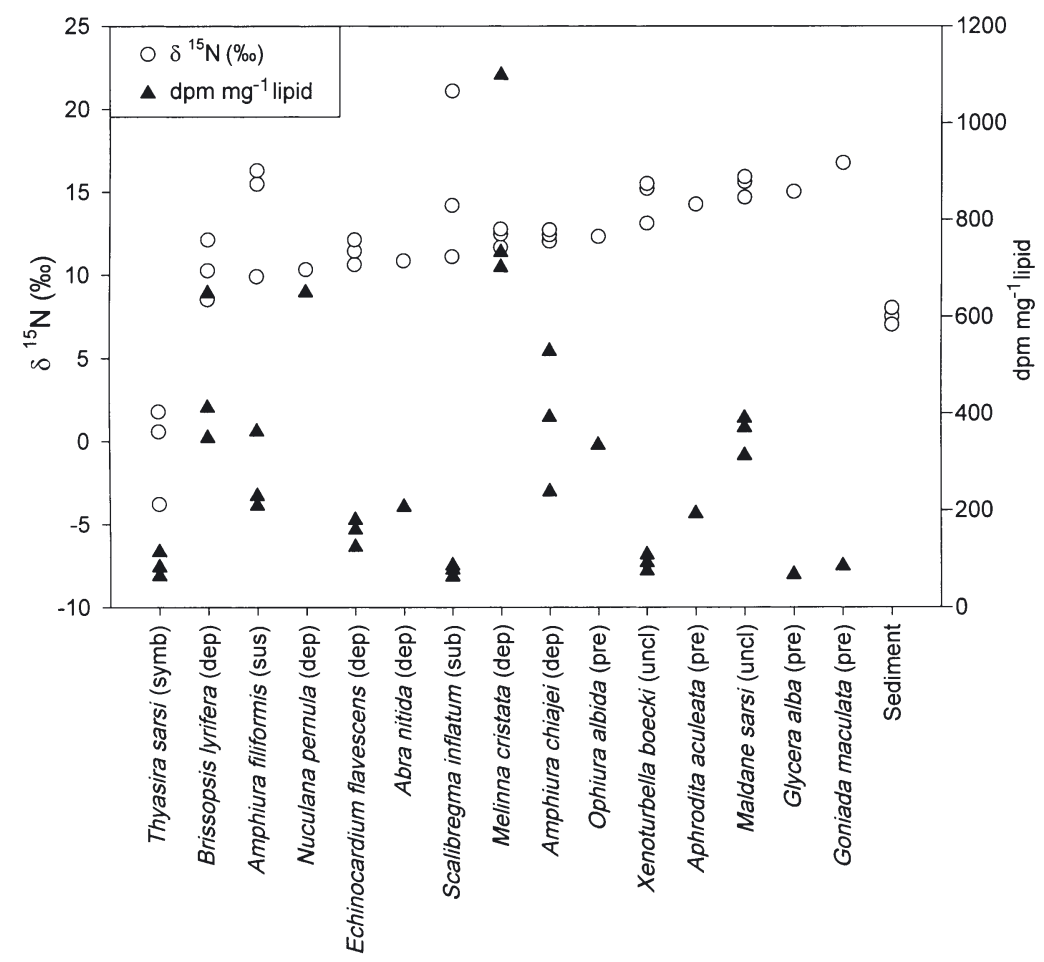

Fig. 6. ${ }^{15} \mathrm{~N}$ enrichment and concentration of ${ }^{14} \mathrm{C}$-BDE-47-derived radioactivity in macrofauna and sediment from box-cosms exposed to the pollutant for $29 \mathrm{wk}$. dep: deposit feeders; sus: suspension feeders; sub: subsurface deposit feeders; pre: predators; uncl.: unclassified

Linear regression between accumulation of ${ }^{14} \mathrm{C}-\mathrm{BDE}-$ 47-derived radioactivity and lipid weight/body size

The lipid weight of the macrofauna constituted 2.65 to $5.62 \%$ of the total bulk-sediment lipid content in the upper $5 \mathrm{~cm}$ of the box-cosms, and the macrofauna had accumulated 1.86 to $5.32 \%$ of the total ${ }^{14} \mathrm{C}$-BDE-47derived radioactivity (activity in both the chloroform and the methanol phase) (Tables $1 \& 4$ ). Linear regression analyses of the relationship between the lipid content (ln-transformed data) and BDE-47-derived activity (dpm, chloroform phase) of all analysed macrofaunal individuals was done for each box-cosm and revealed a significantly positive relationship $(\mathrm{p}<0.01)$ for all boxes $\left(0.11<\mathrm{r}^{2}<0.63\right)$ (Table 5$)$. The variations in $\mathrm{r}^{2}$-values did not correlate with duration of exposure nor with degree (low or high) of exposure to the pollutant.

Similar regression analyses of lipid weight versus radioactivity in the chloroform phase were made for the 3 dominating species in all box-cosms. In Amphiura chiajei and $A$. filiformis no or only a weak positive dependence was found after 10 wk exposure, whereas the dependence was significant and fairly good in all 4 box-cosms after $29 \mathrm{wk}\left(0.40<\mathrm{r}^{2}<0.85\right)$. In Melinna cristata, on the other hand, chloroform-phase activity and the lipid weight of individual animals correlated significantly positively in all boxes after $10 \mathrm{wk}$ exposure $\left(0.42<\mathrm{r}^{2}<0.80\right)$, whereas after 20 and 29 wk there were no correlations in any of the boxes.

No relationship was found between bioaccumulation of the pollutant and dry weight of the animals.

\section{Correlation between accumulation of ${ }^{14} \mathrm{C}-\mathrm{BDE}-47$-derived radioactivity and $\delta^{15} \mathrm{~N}$}

The stable isotope analysis showed that the macrofaunal community in the boxes formed a continuum of overlapping trophic positions (Fig. 6) indicating of a large proportion of omnivorous species (France et al. 1998). $\delta^{15} \mathrm{~N}$ values of $14.3,15.0$ and $16.8 \%$ or the carnivorous polychaetes Aphrodita aculeata (Fauchald \& Jumars 1979), Glycera alba (Ockelman \& Vahl 1970) and Goniada maculata (Mattson 1981) placed these about 2 trophic levels above the bulk sediment. High values, indicative of a predatory feeding mode, were also found for Xenoturbella boecki, whose feeding ecology is virtually unknown, and for Maldane sarsi. The latter is generally considered to be a deposit feeder (Fauchald \& Jumars 1979), but here all 3 individuals had $\delta^{15} \mathrm{~N}$ contents similar to those of the predators. A large variation in values was found in the suspension-feeding brittle star Amphiura filiformis, known for its flexible feeding habits.

No relationship was found between ${ }^{14} \mathrm{C}-\mathrm{BDE}-47$ accumulation (dpm $\mathrm{mg}^{-1}$ lipid) and the ${ }^{15} \mathrm{~N}$ ratio among the investigated species (Fig. 6). On the contrary, when Thyasira sarsi, a species that obtains more than half its nutrition from chemoautotrophic symbiotic bacteria (Spiro \& Greenwood 1986), was excluded from the calculations, the trend was negative, although not significantly so. Predatory species generally had low concentrations of BDE-47, whereas deposit-feeding species like Brissopsis lyrifera, Nuculana pernula and Melinna cristata with lower $\delta^{15} \mathrm{~N}$ values accumulated higher amounts of the pollutant.

\section{Metabolism of BDE-47}

Only 15 of all 41 species represented in the boxcosms had BDE-47-derived radioactivity above the detection limit in the methanol-water phase (Fig. 7). They were of different taxonomic origin, comprising 3 species of brittlestars, 2 bivalves and 10 polychaetes. For many of them, e.g. Abra nitida, Amphiura chiajei, 
Glycera spp., Nephtys spp., Nereis spp. and Ophiura spp., their radioactivity was only approximately $50 \%$ higher than background activity. Amphiura filiformis and 3 species of polychaetes, Melinna cristata, Gattyana amondseni and Rhodine loveni, were the only species whose radioactivity in the methanol-water phase exceeded a few percent (Fig. 7B). The latter 2
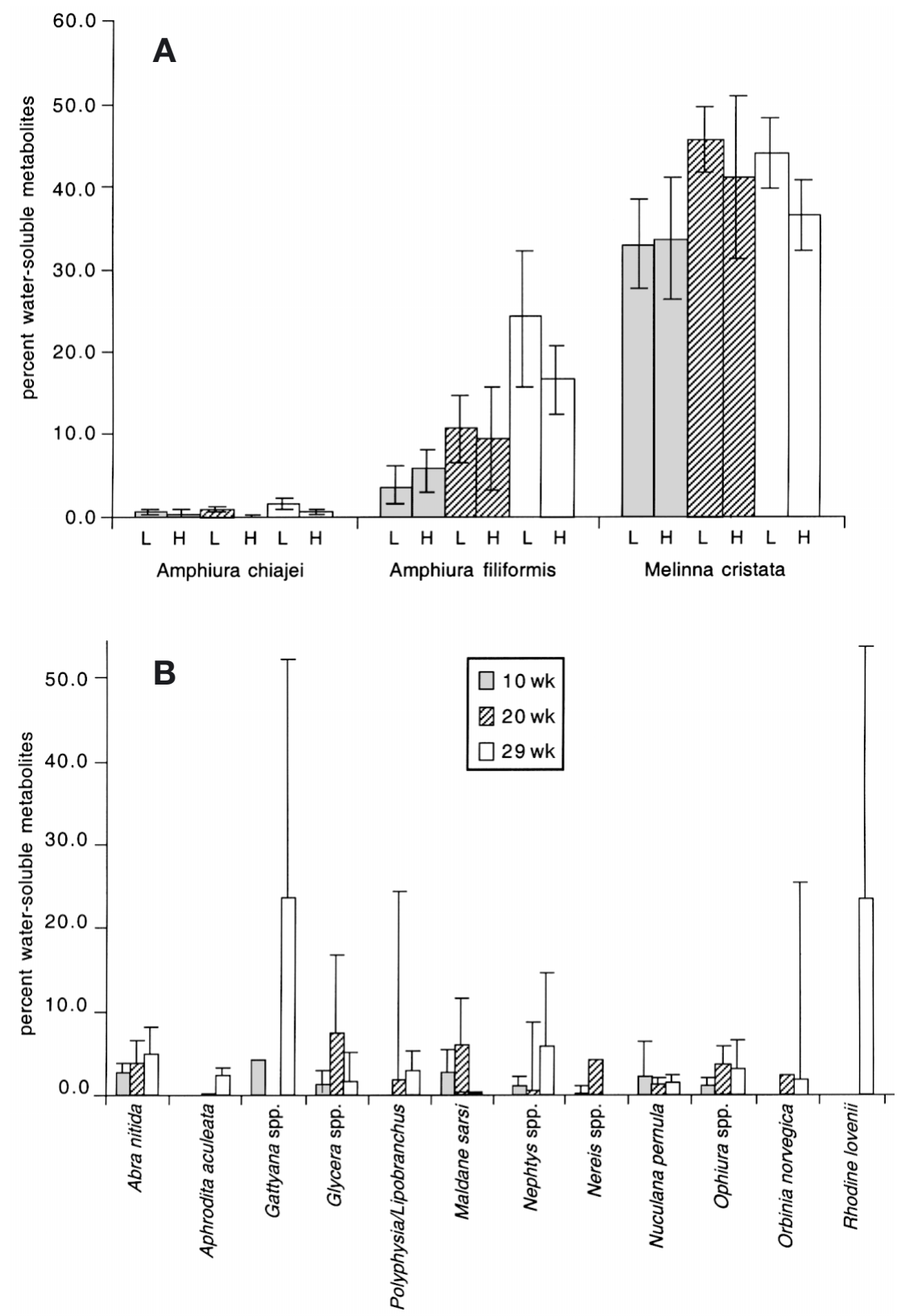

Fig. 7. Average $( \pm 95 \mathrm{CI})$ percentage of total ${ }^{14} \mathrm{C}$-BDE-47-derived radioactivity found in the methanol-water phase of macrofaunal extracts partitioned against chloroform for (A) dominant macrofauna species in box-cosms (data from individual animals were pooled into groups of L-exposed and $\mathrm{H}$-exposed individuals), and (B) all other macrofauna species in which radioactivity in methanol-water soluble fraction of the extracts was detected. In (B) data from all individuals ( $\mathrm{L}$ - and $\mathrm{H}$-exposed) from each species and each sampling occasion were pooled species were represented by very few specimens in the boxes (Table 2).

No correlation was found between the BSAF and the amount of methanol-water soluble metabolites.

The dominating species Melinna cristata had over one-third of the total BDE-47-derived radioactivity in the methanol-water phase on all sampling occasions

(Fig. 7A). Its radioactivity was sometimes 15 times as high as the background levels. In the H-treated boxes the activity remained constant over time, whereas in the L-boxes it increased significantly after 10 wk (ANOVA, $\mathrm{p}=0.014$ ). In Amphiura filiformis radioactivity increased significantly between 10 and 29 wk exposure, but there was no difference between $\mathrm{H}$ and $\mathrm{L}$ treatment. The intraspecific variations were larger in $A$. filiformis than in $M$. cristata. In each box-cosm, 1 or a few individuals of $A$. filiformis had no radioactivity at all in the methanol-water phase. The radioactivity in the methanol-water extracts from A.chiajei was below or very close to detection limit at all times.

\section{DISCUSSION}

\section{Distribution of BDE-47 in sediment}

The downward mixing of ${ }^{14} \mathrm{C}-\mathrm{BDE}-47$ in the sediment was probably the result of faunal activity, since the pollutant was distributed fairly quickly down to a depth of approximately $5 \mathrm{~cm}$ and remained within this sediment layer throughout the experimental period. This is the depth at which the discs of Amphiura chiajei and A. filiformis, 2 of the dominant species (>60\% of the biomass: Table 3), are found. Below this depth only trace amounts of BDE-47-derived radioactivity were detected. These species collect food particles above or on the sediment surface and transport them to their mouth on the bottom side of the disc, thereby providing an efficient downward transport of the particle-associated pollutant. The importance of the fauna for downward mixing of particles in the sediment was shown by Sandnes et al. (2000). In our study, downward mixing rate in the absence of fauna was insignificant.

In the present investigation, the downward mixing of the pollutant was faster in 
boxes with a high dose of BDE-47 than in low-dose boxes. This might be the result of increased macrofaunal activity in the high-dose boxes, a stress response to the addition of the pollutant. A similar phenomenon was previously observed in a box-cosm experiment with tri-n-butyl-tin (Dahllöf et al. 1999).

\section{Biotransformation}

In the current study, it is assumed that the ${ }^{14} \mathrm{C}-\mathrm{BDE}$ 47-derived radioactivity in the methanol-water phase corresponds to metabolites of the compound. This conclusion is strongly supported by the results from the partitioning test with the labelled parent compound and non-contaminated animals, in which a very small and very constant proportion of the radioactivity was found in the methanol-water phase.

There was a large loss of pollutant from the sediment surface over the 29 wk exposure; this was probably partly due to resuspended contaminated particles being flushed out of the system. However, biotransformation of the pollutant, either by fauna or by microorganisms, probably also contributed, since water-soluble metabolites were found both in the fauna and the bulk sediment. The water-soluble metabolite is not very bioavailable, and once excreted from the metabolising organism it would not be taken up again but probably leave the box-cosms with the out-flowing water. An efficient conversion of the mother compound could therefore have an important inhibiting effect on further transfer of the pollutant in the food web.

Analysis of the macrofauna revealed that methanolwater soluble metabolites of ${ }^{14} \mathrm{C}$-BDE- 47 were detectable in a third of the species examined. The proportion of hydrophilic metabolites out of the total ${ }^{14} \mathrm{C}$-BDE-47derived radioactivity varied from only a few percent in some species to almost $50 \%$ in others. The interspecific differences were not related to taxonomic position, e.g. the 2 polychaetes Melinna cristata and Rhodine lovenii contained large proportion of radioactivity in the methanol-water phase, whereas another polychaete, Maldane sarsi, had only trace amounts (Fig. 7), and while levels were high in Amphiura filiformis, they were barely detectable in the other brittlestars, A. chiajei and Ophiura spp.

Even though the metabolic capacity seemed to be low or absent in most macrofaunal species, biotransformation of BDE- 47 could still be of ecological importance if it is effected by very abundant species. In the sediment ecosystem investigated in the present study large amounts of water-soluble metabolites were found in e.g. Amphiura filiformis and Melinna cristata. These 2 species made up approximately $40 \%$ of the total macrofau- nal biomass and contained 0.9 to $3.7 \%$ of the total BDE47-derived radioactivity in the boxes. The radioactivity in the methanol-water phase of $M$. cristata remained fairly constant at approximately $40 \%$ of the radioactivity throughout the experiment, indicating a balance between production and elimination of the metabolites. In A. filiformis, the ratio of hydrophilic metabolites increased with time, which might have been the result of either induction of the metabolic capacity, or a build-up of metabolites within the tissues due to a slow elimination rate. There are very few previous studies on the metabolism of PBDEs, and to our knowledge there are none on invertebrate species. In a study by Örn \& KlassonWehler (1998), the biotransformation of BDE-47 was studied in mice and rats, and in both species hydrophilic metabolites were detected even though there was considerable interspecific difference.

The hydrophilic metabolites of BDE-47 in the extracts of the sediment may have derived either from the fauna or from bacterial transformation of the compound. Natural communities of sediment bacteria have been shown to degrade both naturally and anthropogenically produced brominated organic compounds (Morris et al. 1992, Häggblom 1996, Steward \& Lovell 1997).

An explanation of the more rapid disappearance of ${ }^{14} \mathrm{C}$-BDE-47-derived radioactivity from the H-boxes may be that the higher substrate concentration induced microbial transformation of BDE-47.

\section{Bioaccumulation of BDE-47}

Although the accumulation of ${ }^{14} \mathrm{C}-\mathrm{BDE}-47$ in the investigated species showed large inter- and intraspecific variations, there was a strong correlation with species and not just a random variation among individual specimens.

Bioaccumulation of organic pollutants may be influenced by a number of factors such as differences in lipid content of the exposed animals, differences in their capacity to biotransform the pollutant, or various ecological differences such as position in the food web. In the present study we found that the observed interspecific differences in ${ }^{14} \mathrm{C}$-BDE-47 accumulation could partly be explained by variations in lipid content. The amount of water-soluble (and excretable) metabolites showed no correlation with bioaccumulation. A good example of this is that whereas both Melinna cristata and Maldane sarsi had high concentrations of ${ }^{14} \mathrm{C}$-BDE-47 in the chloroform phase, the amount of hydrophilic metabolites was high in $M$. cristata but barely detectable in M. sarsi. However, it should be emphasised that the amount of water-soluble metabolites is not necessarily correlated with metabolic rate. Biomagnification, i.e. higher lipid-based concentration in an organism than in 
its diet, is an example of how an animal's position in the food web may influence the bioaccumulation of organic pollutants. This phenomenon has been shown to occur in some pelagic food webs (Cabana \& Rasmussen 1994, Russell et al. 1999), but in benthic communities correlations between bioaccumulation and trophic level of the animals are less well investigated. In the present study we used 2 methods to describe the animals' position in the food web: $\delta^{15} \mathrm{~N}$ analysis and division of the species into different feeding guilds. Both these divisions of animal species into different categories were tested for their correlation with accumulation of ${ }^{14} \mathrm{C}-\mathrm{BDE}-47$.

Although the $\delta^{15} \mathrm{~N}$ analysis revealed a span of approximately 2 trophic levels between the bulk sediment and the analysed animals, there was no correlation between trophic level and the ${ }^{14} \mathrm{C}-\mathrm{BDE}-47$ concentration (dpm g ${ }^{-1}$ lipid) in individual animals.

There was, however, a strong relationship between bioaccumulation of the pollutant and the feeding strategy of the animals. Deposit-feeding species collecting food at the sediment surface had the highest BSAF values throughout the experimental period. This was the case also for several species which feed on the surface but have the main part of their bodies several centimetres below the surface, e.g. Amphiura chiajei and Nuculana pernula. Because of the impossible task of finding the exact exposure concentration for each individual animal, an approximation was done in the BSAF calculations by using the pollutant concentration in homogeneously mixed sediment from the top $1 \mathrm{~cm}$. This may have led to underestimates for species feeding below this depth. However, the surface deposit feeders had significantly higher BSAFs than the other feeding guilds on all 3 sampling occasions, and this difference did not decrease with time.

It has been shown that the uptake of organic pollutants is affected by the quality of the organic matrix onto which they are adsorbed, e.g. Amphiura filiformis bioaccumulates PCB more efficiently when the pollutant is adsorbed to labile organic matter than when it is adsorbed to more refractory organic matter (Gunnarsson et al. 1999). Even though, in the present study, there was no measurable depth-dependent difference in organic content in the sediment in the box-cosms, it is possible that the surface material was more labile than sediment deeper down, which would make BDE47 more bioavailable in the surface sediment.

Selective food intake should also influence the bioaccumulation of organic contaminants. Since organic pollutants are tightly associated with organic material in the sediment, they will become enriched to the same extent as organic matter in comparison with the bulk sediment (Boese et al. 1990). This could result in large interspecific variations in pollutant concentration in the gut content of species with different feeding habits.
Several deposit feeders have been shown to selectively ingest particles with a higher organic content than the bulk sediment (Cammen 1980, Lee et al. 1990), but for most species such information is not well documented.

Predacious species generally had low BSAF values in the present study. This was independent of where in the sediment they live or of whether they catch their prey above, on, or below the sediment surface. The difference in bioaccumulation of BDE-47 between them and the surface deposit feeders did not decrease with time, which is a strong indication that the observation is not just the result of a short exposure time. Ophiura spp. was the only predatory species with fairly high BSAF-values. This species lives on the sediment surface and was observed to be very active immediately after addition of the spiked sediment. After the first $10 \mathrm{wk}$ of exposure it had BSAF values similar to the surface deposit feeders. However, thereafter these values remained constant over the entire experimental period, whereas they had increased on each sampling occasion in the surface deposit feeders. We argued earlier that intake of contaminated food with high digestibility may lead to a high uptake of organic pollutants. It is therefore surprising to find that the predators, which feed on material that ought to be very easily digested compared to the mixed food of deposit feeders, were never among the highest accumulating species on any sampling occasion (Fig. 4). An efficient metabolism of BDE-47 could have explained a low bioaccumulation, but only about half of the predators, the polychaetes Gattyana amondseni, Glycera spp. and Nephtys spp. and the brittlestar Ophiura spp., had detectable amounts of methanol-water soluble metabolites of ${ }^{14} \mathrm{C}-\mathrm{BDE}-47$, and there were no indications of a lower degree of bioaccumulation with increasing radioactivity in the hydrophilic phase.

For many species, the BSAF increased with time, in particular between 20 and 29 wk of exposure (Fig. 3). This increase could indicate that a steady state in pollutant concentration between animal and sediment had not been reached. However, it is important to remember that BSAF is the ratio between the concentration in the animal and the concentration in the sediment. In the present investigation the ${ }^{14} \mathrm{C}-\mathrm{BDE}-47$ concentration declined in many species between the first and the last sampling occasion. Still, the decline was generally not as rapid as in the sediment, resulting in increasing BSAF values with time. Thus, the increased BSAF-values could be the result of a very slow elimination rate of BDE-47 compared to the uptake rate. It is also possible that metabolites of BDE-47 had become covalently bound to lipids, as was observed in a study by Örn \& Klasson-Wehler (1998) when rats and mice were exposed to BDE-47. If such bonds were formed by species in the present investigation, part of the 
BDE-47-metabolites that normally would be watermethanol soluble would end up in the chloroform fraction of the extracts and mistakenly be considered as unmetabolised substances or Phase I metabolites. These lipid-BDE-47 metabolite adducts would probably be long-lived in an organism.

\section{Conclusions}

Most of the recovered ${ }^{14} \mathrm{C}-\mathrm{BDE}-47$ was retained in the uppermost sediment layer throughout the experimental period of $29 \mathrm{wk}$.

Hydrophilic metabolites of the BDE-47 were found in 15 of the 41 analysed macrofauna species, showing that faunal biotransformation of the pollutant had taken place.

The accumulation of BDE-47 in the macrofauna differed considerably between species. The variations depended strongly on the feeding strategies of the animals, and also to some extent on their lipid content. The highest BSAF values were found among the surface deposit feeders, which had values significantly higher than those of suspension feeders, subsurface deposit feeders and predators.

Trophic level in the food web, measured as ${ }^{15} \mathrm{~N}$ enrichment, did not correlate at all with the degree of bioaccumulation of the pollutant.

Acknowledgements. Financial support for the study was given by the Swedish Environmental Protection Agency (001-021-9701), Kungliga och Hvitfeldtska stipendiestiftelsen, Birgit och Birger Wåhlstöms minnesfond, Stiftelsen Wilhelm och Martina Lundgrens Vetenskapsfond och stiftelsen Lars Hiertas Minne. We thank Professor Å. Bergman and Ulrika Örn at the Department of Environmental Chemistry, Stockholm University, for providing us with ${ }^{14} \mathrm{C}-\mathrm{BDE}-47$ and unlabelled BDE-47, Bo Edlén at the Department of Zoology, Stockholm University, for the ${ }^{15} \mathrm{~N} /{ }^{14} \mathrm{~N}$ analysis, and Professor Hans Blanck, Department of Botany, for valuable comments on the manuscript.

\section{LITERATURE CITED}

Berge JA, Schaanning M, Bakke T, Sandøy KA, Skeie GM, Ambrose Jr WG (1986) A soft-bottom sublittoral mesocosm by the Oslofjord: description, performance and examples of application. Ophelia 26:37-54

Bligh EG, Dyer WJ (1959) A rapid method of total lipid extraction and purification. Can J Biochem Physiol 37:912-917

Boese BL, Lee H II, Specht DT, Randall RC (1990) Comparison of aqueous and solid-phase uptake for hexachlorobenzene in the tellinid clam Macoma nasuta (Conrad): a mass balance approach. Environ Toxicol Chem 9:221-231

Broman D, Näf C, Lundbergh I, Zebühr Y (1990) An in situ study on the distribution, biotransformation and flux of polycyclic aromatic hydrocarbons (PAHs) in an aquatic food chain (seston-Mytilus edulis L.-Somateria mollisima L.) from the Baltic: an ecotoxicological perspective. Environ Toxicol Chem 9:429-442
Cabana G, Rasmussen JB (1994) Modelling food chain structure and contaminant bioaccumulation using stable nitrogen isotopes. Nature 372:255-257

Cammen LM (1980) Ingestion rate: an empirical model for aquatic deposit feeders and detrivores. Oecologia 44: $303-310$

Dahllöf I, Blanck H, Hall POJ, Molander S (1999) Long-term effects of tri- $n$-butyl-tin on the function of a marine sediment system. Mar Ecol Prog Ser 188:1-11

Dahllöf I, Agrenius S, Blanck H, Hall P, Magnusson K, Molander S (2001) The effect of TBT on the structure, of a marine sediment community - a boxcosm study. Mar Pollut Bull 42:689-695

De Ridder C (1982) Feeding and some aspects of the gut structure in the spatangoid echinoid, Echinocardium cordatum (Pennant). In: Lawrence JM (ed) Proc 4th Int Echinoderms Conf, Tampa, 1981. A. A. Balkema, Rotterdam, p 5-9

Di Toro DM, Zarba CS, Hansen DJ, Berry WJ and 6 others (1991) Technical basis for establishing sediment quality criteria for nonionic organic chemicals using equilibrium partitioning. Environ Toxicol Chem 10:1541-1583

Fauchald K, Jumars PA (1979) The diet of worms: a study of polychaete feeding guilds. Oceanogr Mar Biol Annu Rev 17:193-284

Forbes TL, Forbes VE, Giessing A, Hansen R, Kure LK (1998) Relative role of pore water versus ingested sediment in bioavailability of organic contaminants in marine sediments. Environ Toxicol Chem 17:2453-2462

France R, Chandler M, Peters R (1998) Mapping trophic continua of benthic foodwebs; body size $-\delta^{15} \mathrm{~N}$ relationships. Mar Ecol Prog Ser 174:301-306

Fry B (1988) Food web structure on Georges Bank from stable $\mathrm{C}, \mathrm{N}$ and $\mathrm{S}$ isotopic compositions. Limnol Oceanogr 33: $1182-1190$

Goerke H, Weber K (2001) Species-specific elimination of polychlorinated biphenyls in estuarine animals and its impact on residue patterns. Mar Environ Res 51:131-149

Gunnarsson JS, Granberg ME, Nilsson HC, Rosenberg $\mathrm{R}_{\text {, }}$ Hellman B (1999) Influence of sediment-organic matter quality on growth and polychlorobiphenyl bioavailability in Echinodermata (Amphiura filiformis). Environ Toxicol Chem 18:1534-1543

Häggblom MM (1996) Diversity of anaerobic microbial processes in haloaromatic degradation. Int Biodeterior Biodegrad 37:244

Hobson KA, Welch HE (1992) Determination of trophic relationships within a high Arctic marine food web using $\delta^{13} \mathrm{C}$ and $\delta^{15} \mathrm{~N}$ analysis. Mar Ecol Prog Ser 84:9-18

Hollertz K (1998) The response of Brissopsis lyrifera (Echinodea: Spatangoida) to organic matter on the sediment surface. In: Carnevali MDC, Bonasoro F (eds) Proc 5th Eur Conf Echinoderms, Italy. A. A. Balkema, Rotterdam, p 79-84

Jansson B, Andersson R, Asplund L, Litzén K and 7 others (1993) Chlorinated and brominated persistent organic compounds in biological samples from the environment. Environ Toxicol Chem 12:1163-1174

Kaehler S, Pakhomov EA, McQuaid CD (2000) Trophic structure of the marine food web at the Prince Edward Islands (Southern Ocean) determined by $\delta^{13} \mathrm{C}$ and $\delta^{15} \mathrm{~N}$ analysis. Mar Ecol Prog Ser 208:13-20

Lake JL, Rubinstein NI, Lee H II, Lake CA, Heltshe J, Pavignano $S$ (1990) Equilibrium partitioning and bioaccumulation of sediment-associated contaminants by infaunal organisms. Environ Toxicol Chem 9:1095-1106

Lee HL II, Boese BL, Randall RC, Pelletier J (1990) A method for determining gut uptake efficiencies of hydrophobic 
pollutants in a deposit-feeding clam. Environ Toxicol Chem 9:215-219

Lindström G, Wingfors H, Dam M, van Boer B (1999) Identification of 19 polybrominated diphenyl ethers (PBDEs) in long-finned pilot whale (Globicephala melas) from the Atlantic. Arch Environ Contam Toxicol 36:355-363

Loo LO, Jonsson PR, Sköld M, Karlsson Ö (1996) Passive suspension feeding in Amphiura filiformis (Echinodermata: Ophiuroidea): feeding behaviour in flume flow and potential feeding rate of field populations. Mar Ecol Prog Ser 139:143-155

Lopez GR, Levinton JS (1987) Ecology of deposit-feeding animals in marine sediments. Quart Rev Biol 62:235-259

Mackay D, Fraser A (2000) Bioaccumulation of persistent organic chemicals: mechanisms and models. Environ Pollut 110:375-391

Mattson S (1981) Burrowing and feeding of Goniada maculata Ørsted (Polychaeta). Sarsia 66:49-51

Minagawa M, Wada E (1984) Stepwise enrichment of ${ }^{15} \mathrm{~N}$ along food chains: further evidence and relation between $\delta^{15} \mathrm{~N}$ and animal age. Geochim Cosmochim Acta 48: $1135-1140$

Morris PJ, Quensen JFI, Tiedje JM, Boyd SA (1992) Reductive debromination of the commercial polybrominated biphenyl mixture firemaster BP6 by anaerobic microorganisms from sediments. Appl Environ Microbiol 58:3249-3256

Norén K, Meironyté D (2000) Certain organochlorine and organobromine contaminants in Swedish human milk in perspective of past 20-30 years. Chemosphere 40: 1111-1123

Nylund K, Asplund L, Jansson B, Jonsson P, Litzén K, Sellström U (1992) Analysis of some polyhalogenated organic pollutants in sediment and sewage sludge. Chemosphere 24:1721-1730

Editorial responsibility: Otto Kinne (Editor),

Oldendorf/Luhe, Germany
Ockelman KW, Vahl O (1970) On the biology of the polychaete Glycera alba, especially its burrowing and feeding. Ophelia 8:275-294

Örn U, Klasson-Wehler E (1998) Metabolism of 2,2', 4, 4'tetrabromodiphenyl ether in rat and mouse. Xenobiotica 28:199-211

Ruppert EE, Barnes RD (1994) Invertebrate zoology, 6th edn. Brooks/Cole, Thomson learning, Stanford, CT

Russell RW, Gobas FAPC, Haffner GD (1999) Role of chemical and ecological factors in trophic transfer of organic chemicals in aquatic food webs. Environ Toxicol Chem 18:1250-1257

Sandnes J, Forbes T, Hansen R, Sandnes B (2000) Influence of particle type and faunal activity on mixing of di(2-ethylhexyl)phtalate (DEHP) in natural sediments. Mar Ecol Prog Ser 197:151-167

Sellström U, Kierkegaard A, de Wit C, Jansson B (1998) Polybrominated diphenyl ethers and hexabromocyclododecane in sediment and fish from a Swedish river. Environ Toxicol Chem 17:1065-1072

Silversand C, Haux C (1995) Fatty acid composition of vitellogenin from four teleost species. J Comp Physiol B Biochem Syst Environ Physiol 164:593-599

Spiro B, Greenwood PB $(1986){ }^{13} \mathrm{C} /{ }^{12} \mathrm{C}$ ratios in marine invertebrates from reducing sediments: confirmation of nutritional importance of chemoautotrophic endosymbiotic bacteria. Mar Ecol Prog Ser 29:233-240

Steward CC, Lovell CR (1997) Respiration and assimilation of 4-bromophenol by estuarine sediment bacteria. Microb Ecol 33:198-205

Strandberg B, Bandh C, van Bavel B, Bergqvist PA, Broman D, Ishaq R, Näf C, Rappe C (2000) Organochlorine compounds in the Gulf of Bothnia: sediment and benthic species. Chemosphere 40:1205-1211

Submitted: March 3, 2001; Accepted: February 11, 2003

Proofs received from author(s): May 22, 2003 